\title{
The Sino-Philippine Arbitration on the South China Sea Disputes and the Taiwan Factor
}

\section{Michael Sheng-ti Gau*}

The Sino-Philippine Arbitration on the South China Sea Disputes was over on July 12, 2016, with a Merits Award in Philippine favor. Beijing rejected this arbitration and abstained from submitting written and oral arguments. Taiwan actively engaged in the debate with the Philippines since July 7, 2015. Not deemed as representative of China, Taiwan was considered capable of clarifying the meaning of the U-Shaped Line it first published in 1947 when seated in Nanjing, representing China then. The biggest maritime feature in the Spratly Islands, i.e. Taiping Island (Itu Aba), has been occupied by troops from mainland China since 1946 and then from Taiwan since 1956. The legal status of Taiping Island was the key to success of Philippine Submissions. The factual information from Taiwan became vital. This paper examines Taiwan's role in this arbitration and the degree to which it could actually speak for China at such legal proceedings.

\section{Keywords}

South China Sea Arbitration, UNCLOS, Annex VII-Tribunal, Taiping Island, U-Shaped Line, Article 121 of UNCLOS

* Professor of International Law at the Institute for the Law of the Sea, National Taiwan Ocean University. LL.B.(NTU), LL.M. (Cantab/London), Ph.D. (Leiden). The views expressed in this paper are those of the author and do not represent the official position of any government agencies or other people. The author may be contacted: mikegau97@msn.com / Address: No. 1, Peining Road, Keelung City, 20224, Taiwan. DOI: http://dx.doi.org/10.14330/jeail.2016.9.2.09 


\section{Introduction}

The Sino-Philippine Arbitration for the South China Sea ("SCS") Disputes finally ended on July 12, 2016, with a Merits Award totally in Philippine favor. As the respondent, China rejected this arbitration as well as the Awards on Jurisdiction, Admissibility and Merits. Meanwhile, the Government in Taiwan (hereinafter Taiwan) started to publish legal arguments and factual information from July 7, 2015 to refute the Philippines' relevant arguments for this arbitration. It is interesting to review the role of Taiwan in this arbitration. In this research, the author will outline the development of this arbitration where the interactions between Taiwan, the Philippines, and the Tribunal will be focused stage by stage. This paper is composed of four parts including a short Introduction and Conclusion. Part two will examine the beginning and evolution of the SCS Arbitration. Part three will address Taiwan's role through this Arbitration.

\section{Development of SCS Arbitration}

\section{A. Initiation of the Arbitration}

On January 22, 2013, the Philippines invoked Article 287 and Annex VII of the UNCLOS $^{1}$ for initiating an arbitration against China. ${ }^{2}$ The Notification and Statement of Claim (hereinafter the Notification) said that the goal of this action was "to seek a peaceful and durable resolution of the dispute in the West Philippine Sea ("WPS"),", by narrowing disputes to facilitate future negotiation. ${ }^{4}$ The Philippines challenged China's maritime entitlements and claims, land reclamation, enforcement and military actions and omissions within WPS located in the eastern part of SCS

1 United Nations Convention on the Law of the Sea of 1982, 1833 U.N.T.S. 3 (1982) [hereinafter UNCLOS].

2 See Statement by the Secretary of DFA on the UNCLOS Arbitral Proceedings against China, available at http://www. imoa.ph/press-releases/statement-by-secretary-of-foreign-affairs-albert-del-rosario-on-the-unclos-arbitral-proceedingsagainst-china-to-achieve-a-peaceful-and-durable-solution-to-the-dispute-in-the-wps (last visited on Oct. 31, 2016).

3 See Notification and Statement of Claims, issued by Department of Foreign Affairs of the Philippines to the Chinese Embassy in Manila, at 1, ๆ 1, Serial No. 13-0211, Jan. 22, 2013, available at http://www.philippineembassy-usa.org/ uploads/pdfs/embassy/2013/2013-0122-Notification $\% 20$ and $\% 20$ Statement $\% 20$ of $\% 20$ Claim $\% 20$ on $\% 20$ West $\% 20$ Philippine\%20Sea.pdf (last visited on Oct. 31, 2016).

4 Oral statement by Solicitor General Hilbay on July 7, 2015, Final Transcription Day 1-Jurisdiction Hearing, at 8, available at https:/pcacases.com/web/view/7 (last visited on Oct. 31, 2016). This website contains all information about this arbitration. 
enclosed by the U-Shaped Line ("USL").

Five groups of claims were presented by the Notification. ${ }^{5}$ First, China's rights concerning the SCS maritime areas are those established by the UNCLOS only and consist of territorial sea, contiguous zone, Exclusive Economic Zone ("EEZ") and continental shelf; China's maritime claims therein based on USL contravene the UNCLOS and are invalid. Second, Mischief, McKennan, Gaven and Subi Reefs are low-tide elevations ("LTEs"), instead of 'islands' or 'rocks' under Article 121. None of them are located in China's continental shelf. Mischief and McKennan Reefs are part of the Philippine continental shelf. Thus, China's occupation of these four maritime features and construction activities thereon are unlawful and should be terminated. Third, Johnson, Cuarteron, and Fiery Cross Reefs as well as Scarborough Shoal are rocks under Article 121(3) which may generate territorial sea only. Having unlawfully claimed maritime entitlements beyond 12 nautical miles ("nm") from these features, China should refrain from preventing Philippine vessels from exploiting living resources in waters adjacent to Scarborough Shoal and Johnson Reef, and from undertaking other activities inconsistent with the UNCLOS at or in the vicinity of these features. Fourth, the Philippines is entitled under the UNCLOS to a $12 \mathrm{~nm}$ territorial sea, a $200 \mathrm{~nm}$ EEZ, and a continental shelf measured from its archipelagic baselines on WPS. China has unlawfully claimed and exploited the natural resources in this EEZ and continental shelf, and prevented the Philippines from exploiting the living and non-living resources therein. Fifth, China has unlawfully interfered with Philippine exercise of its navigational rights and other rights under the UNCLOS within and beyond the Philippine EEZ. China should desist from these unlawful activities. ${ }^{6}$

As China rejected the Philippines' arbitration request from the very beginning, ${ }^{7}$ its complaints against the Philippines were missing in the Submissions. ${ }^{8}$ China's refusal was based on, inter alia, its 2006 Declaration, ${ }^{9}$ which, from China's perspectives,

5 For comments, see Michael S.T. Gau, The Sino-Philippine Arbitration on South China Sea (Nine-Dash-Line) Dispute: Applying the Rule of Default of Appearance, 28 OCEAN Y.B. 81-133 (2014).

6 Supra note $3, \boldsymbol{q} \uparrow 31 \& 41$.

7 See Statement by the Spokesperson of the Foreign Ministry of China, Feb. 9, 2013, available at http://www.fmprc.gov. $\mathrm{cn} / \mathrm{eng} / \mathrm{xwfw} / \mathrm{s} 2510 / 2511 / \mathrm{t} 1015317 . \mathrm{shtml}$ (last visited on Oct. 31, 2016).

8 Had China decided to join the arbitration, it would have put its territorial disputes with the Philippines into the Submissions for the Tribunal to entertain, as the Philippines since 1970s occupied several islands in the Spratly Islands Group claimed by China. China has been strongly opposed to such Philippine invasions ever since. Had such Submissions been joined, the Tribunal would have ruled them inadmissible as such submissions would not have been concerning the interpretation or application of the UNCLOS. See China's Position Paper, 9 甲 6-7, available at http://www.fmprc.gov.cn/ mfa_eng/zxxx_662805/t1217147.shtml (last visited on Oct. 31, 2016).

9 China's declaration of August 25, 2006 reads: "The Government of the People's Republic of China does not accept any of the procedures provided for in Section 2 of Part XV of the Convention with respect to all the categories of disputes 
has covered the disputes submitted by the Philippines and deprived the Tribunal's jurisdiction to entertain the case. The default rules were applied to appoint arbitrators and establish the arbitral tribunal. ${ }^{10}$

On July 11, 2013, the Members of the Tribunal decided to use the Permanent Court of Arbitration ("PCA") as Registry. ${ }^{11}$ The Tribunal soon adopted the PHCN Rules of Procedure ("ROP") and fixed March 30, 2014 as the deadline for the Philippines to submit its Memorial. Knowing that China has jurisdictional objections, the Tribunal directed the Philippines to fully address the issues of jurisdiction, admissibility, and merits in the Memorial. ${ }^{12}$

\section{B. The Philippine Memorial and Written Arguments}

The Philippines submitted the Memorial ${ }^{13}$ largely corresponding to the structure of the Notification. The Memorial requested the Tribunal to adjudge and declare that:

1. China's maritime entitlements in the SCS, like those of the Philippines, may not extend beyond those permitted by UNCLOS;

2. China's claims to sovereign rights and jurisdiction, and to 'historic rights', with respect to SCS maritime areas encompassed by USL are contrary to UNCLOS and without lawful effect to the extent that they exceed the geographic and substantive limits of China's maritime entitlements under UNCLOS;

3. Scarborough Shoal generates no EEZ or continental shelf;

4. Mischief Reef, Second Thomas Shoal and Subi Reef are LTEs incapable of generating territorial sea, EEZ or continental shelf, and incapable of appropriation by occupation or otherwise;

5. Mischief Reef and Second Thomas Shoal are part of Philippine EEZ and continental shelf;

6. Gaven and McKennan Reefs (including Hughes Reef) are LTEs incapable of generating territorial sea, EEZ or continental shelf, but their low-water line may be used to determine the baseline from which the breadth of territorial sea of Namyit and Sin Cowe, respectively, is measured;

referred to in paragraph 1 (a) (b) and (c) of Article 298 of the Convention." See Declaration made after ratification (Aug. 25, 2006), available at $\mathrm{http} / /$ www.un.org/Depts/los/convention_agreements/convention_declarations.htm\#China upon ratification (last visited on Oct. 31, 2016).

10 Supra note 1, annex VII, art. 3(e).

11 PCA First Press Release (Aug. 27, 2013).

12 Id. It seems that the Tribunal did not intend to bifurcate the proceedings then.

13 For the text and annexes of the Memorial, see supra note 4. For details, see also Michael S.T. Gau, The Sino-Philippine Arbitration on South China Sea Disputes: Admissibility and Jurisdiction Issues, 21 China Oceans L. Rev. 64-293 (2015). 
7. Johnson, Cuarteron and Fiery Cross Reefs generate no EEZ or continental shelf;

8. China has unlawfully interfered with the enjoyment and exercise of Philippine sovereign rights with respect to the living and non-living resources of Philippine EEZ and continental shelf;

9. China has unlawfully failed to prevent its nationals and vessels from exploiting the living resources in Philippine EEZ;

10. China has unlawfully prevented Philippine fishermen from pursuing their livelihoods by interfering with traditional fishing activities at Scarborough Shoal;

11. China has violated its UNCLOS obligations to protect and preserve the marine environment at Scarborough Shoal and Second Thomas Shoal;

12. China's occupation of and construction activities on Mischief Reef: (a) violate UNCLOS provisions concerning artificial islands, installations, and structures; (b) violate China's UNCLOS duties to protect and preserve the marine environment; and (c) constitute unlawful act of attempted appropriation against UNCLOS;

13. China has breached its UNCLOS obligation by operating its law enforcement vessels dangerously causing serious risk of collision to Philippine vessels navigating in the vicinity of Scarborough Shoal;

14. Since the commencement of this arbitration in January 2013, China has unlawfully aggravated and extended the dispute by, inter alia: (a) interfering with Philippine rights of navigation in the waters at, and adjacent to, Second Thomas Shoal; (b) preventing the rotation and resupply of Philippine personnel stationed at Second Thomas Shoal; and (c) endangering the health and well-being of Philippine personnel stationed at Second Thomas Shoal; and

15. China shall desist from further unlawful claims and activities. ${ }^{14}$

On December 5, 2014, the Tribunal received "Statement of the Ministry of Foreign Affairs of Viet Nam for the attention of the Tribunal in the Proceedings between the Philippines and PRC,"15 affirming Tribunal's jurisdiction over the disputes before it. ${ }^{16}$ On December 7, 2014, the "Position Paper of PRC Government on the Matter of Jurisdiction in the SCS Arbitration Initiated by the Philippines (hereinafter Position Paper)" was released. Denying Tribunal's jurisdiction over the disputes presented by the Philippines, the Position Paper was neither meant to be a Counter-Memorial, ${ }^{17}$

14 Id. See also The Philippines Memorial (vol. 1), at 271-2, available at http://www.pcacases.com/pcadocs/Memorial\%20 of $\% 20$ the $\% 20$ Philippines $\% 20$ Volume\%20I.pdf (last visited on Oct. 31, 2016).

15 See Third Press Release (Dec. 17, 2014).

16 The South China Sea Arbitration Award before An Arbitral Tribunal Constituted under Annex VII to the UNCLOS between the Philippines and P.R. China (PCA Case No 2013-19) [hereinafter Merits Award], ๆ 36, available at https:// pca-cpa.org/wp-content/uploads/sites/175/2016/07/PH-CN-20160712-Award.pdf (last visited on Oct. 31, 2016).

17 China's Position Paper, supra note 8. For details, see N. Klein, The Limitations of UNCLOS Part XV in Resolving South China Sea Disputes, 31 InT'L J. MARINe \& COASTAL L. 8-15 (2016), available at http://papers.ssm.com/sol3/ 
nor treated as such. ${ }^{18}$ Article 25(2) of $\mathrm{ROP}^{19}$ became applicable.

Accordingly, the Tribunal gave the Philippines 26 questions to be answered before March 15, 2015 as "Further Written Arguments." China is requested to comment by June 15, 2015. ${ }^{20}$ China declined. The hearing took place on July 7-13, 2015 (July Hearing) in the Peace Palace, to address the jurisdictional and admissibility issues. ${ }^{21}$

\section{The Jurisdictional Award}

On October 29, 2015 the PCA released the Award on Jurisdiction and Admissibility (Jurisdictional Award), moving all Philippine Submissions into the merits phase. ${ }^{22}$ Submissions 1-4, 6-7 and 10-14 were held to reflect disputes concerning the interpretation or application of the UNCLOS, while not relating to sovereignty or concerning sea boundary delimitation. Submissions 5 and 8-9 were held to reflect disputes while not relating to sovereignty. For Submissions 1-2, 5, 8-9, 12 and 14, there remain unresolved jurisdictional issues not of exclusively preliminary nature. The Tribunal decided to move these seven Submissions into Merits Phase to settle the remaining jurisdictional issues. ${ }^{23}$

\section{Second Hearing and the Amended Submissions}

The second hearing was held on November 24-30, 2015 (November Hearing) to discuss the remaining issues of jurisdiction and admissibility as well as the merits issues. ${ }^{24}$ Without China's presence, the Hearing ended with extra Final Submissions

\footnotetext{
papers.cfm?abstract_id=2730411 (last visited on Aug. 22, 2016).

18 Supra note 15.

19 ROP art. 25(2), available at https://pcacases.com/web/sendAttach/233 (last visited on Aug. 31, 2016).

20 Supra note 15.

21 For Transcripts of the July Hearing, see supra note 4. For details, see Michael S.T. Gau, The Sino-Philippine Arbitration on the South China Sea Disputes: Ineffectiveness of the Award, Inadmissibility of the Claims, and Lack of Jurisdiction, With Special Reference to the Legal Arguments Made by the Philippines in the Hearing on 7-13 July 2015, 21 CHINA OCEANS L. Rev. 1-207 (2015).

22 For the Award on Jurisdiction and admissibility [hereinafter Jurisdictional Award], see supra note 4. For details, see C. Whomersley, The South China Sea: The Award of the Tribunal in the Case Brought by the Philippines against China - A Critique, 15 ChINESE J. INT'L L. (2016), available at http:/chinesejil.oxfordjournals.org/content/early/2016/06/06/ chinesejil.jmw011.full.pdf+html; Michael S.T. Gau, The Agreements and Disputes Crystalized by the 2009-2011 Sino-Philippine Exchange of Notes Verbales and their Relevance to the Jurisdiction and Admissibility Phase of the South China Sea Arbitration, 15 CHINESE J. INT'L L. (2016), available at http://chinesejil.oxfordjournals.org/content/ early/2016/08/19/chinesejil.jmw023.full.pdf?keytype=ref\&ijkey=88VuZV3gOXGKlj0 (all last visited on Oct. 31, 2016).

23 Jurisdictional Award, ๆๆ 397-413.

24 For Transcripts on Merits Hearing, see supra note 4.
} 
11, 14(d) and 15 from the Philippines, primarily concerning island-building, environmental harms and aggravation of the disputes done by China in Mischief, Cuarteron, Fiery Cross, Gaven, Johnson, Hughes and Subi Reefs. ${ }^{25}$

\section{E. The Merits Award}

On July 12, 2016, the Merits Award was released. ${ }^{26}$ Among the 15 Philippine Final Submissions, only Submissions 14(a) to (c) and 15 failed to surmount the thresholds of jurisdiction and admissibility. The Tribunal's rulings on the merits were totally in favor of the Philippines concerning Final Submissions 1-13 and 14(d). However, among China-occupied or controlled maritime features, six were held as rocks and five LTEs. ${ }^{27}$ Moreover, none of the high-tide features in the Spratly Islands may generate EEZ and continental shelf under Article 121(3). ${ }^{28}$ Archipelagic or straight baselines may not be used to enclose the Spratly Islands as a unit. ${ }^{29}$

\section{Taiwan's Role in the SCS Arbitration}

\section{A. The Initial Stage}

The 'effective control' principle underpinned the Philippine formulation of Submissions in determining China's maritime entitlements in WPS. In the Notification, the Philippines identified all eight maritime features occupied by Beijing Government, while requesting the Tribunal to decide their legal status. The Philippines contended that four of them were only 'LTEs' incapable of generating territorial sea, while the remaining four were 'rocks' capable of generating territorial sea only. Without EEZ and continental shelf in WPS, China's law enforcement activities there should be deemed 'trespassing' into the Philippine EEZ and continental shelf. ${ }^{30}$

Whether 'Taiwan factor' should be ignored by the Notification in this context seemed a hard choice, as Taiwan occupies the biggest island in the Spratly Islands, i.e., Itu Aba (Taiping Island). With fresh water and human community, Itu Aba has been

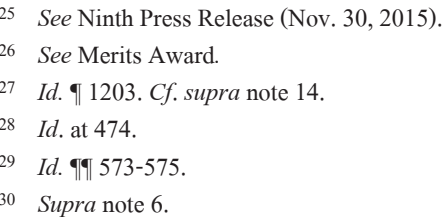


widely regarded as a fully qualified island under Article $121 .^{31}$ Should the EEZ and continental shelf generated by Itu Aba accrue to China, the positions that "China has no EEZ and continental shelf in WPS" and "China trespassed into Philippine EEZ and continental shelf" would fail. If ignoring Itu Aba, the Philippines would violate the "One-China Principle" it adheres. ${ }^{32}$ Totally omitted by the Notification, the Itu Aba factor was soon voiced at several international conferences since May 2013. ${ }^{33}$ Later on, the Philippines' Memorial changed strategy for maintaining that China has no EEZ and continental shelf in WPS.

\section{B. Taiwan Factor in the Philippines' Memorial and Written Arguments}

Without corresponding 'Submission' at the end, the Memorial identified three largest maritime features (i.e., Itu Aba, Thitu, and West York) in the Spratly Islands, arguing that they did not qualify as 'islands.' Therefore, none of the maritime features in the Spratly Islands may generate EEZ or continental shelf for China. This new arguments minimized the potential tensions that might arise between the Philippines and other claimants States in SCS, as Thitu and West York are occupied by the Philippines. The maritime features occupied by Viet Nam and Malaysia were not mentioned.

Such an argument needed further refinement as some leading scholars in their contemporaneous work consider that at least twelve islands exist in the Spratly Islands. ${ }^{34}$ Question 22 raised by the Tribunal on December 16, 2014 requested the Philippines to provide written arguments on the status of any China-claimed maritime features that could give rise to EEZ or continental shelf reaching all those nine

31 R. Beckman, The UN Convention on the Law of the Sea and the Maritime Disputes in the South China Sea, 107 AM. J. INT'L L. 144 (2013), available at http://cil.nus.edu.sg/wp/wp-content/uploads/2010/08/Beckman-THE-UNCONVENTION-ON-THE-LAW-OF-THE-SEA-AND-THE-MARITIME-DISPUTES-IN-THE-SCS.pdf; BeckmanTHE-UN-CONVENTION-ON-THE-LAW-OF-THE-SEA-AND-THE-MARITIME-DISPUTES-IN-THE-SCS.pdf. See also R. Smith, Maritime delimitation in the South China Sea: Potentiality and Challenges, 41 OcEAn Dev. \& InT'L L. 222 (2010), available at http://www.tandfonline.com/doi/abs/10.1080/00908320.2010.499315 (all last visited on Oct. 31, 2016).

32 Final Transcript Day 2-Merits Hearing (November 25, 2015) and corresponding text.

33 See, e.g., Michael S.T. Gau, Preliminary Comments on the Arbitration between the Philippines and China on South China Sea (9 Dash Line) Disputes, presented at the 2013 ILA-ASIL Asia-Pacific Research Forum, May 15-16, 2013 in Taipei. See also supra note 5.

34 R. Beckman \& C. Schofield, Defining EEZ Claims from Islands: A Potential South China Sea Change, 29 InT'L J. MAR. \& COASTAL L. 210-1 (2014), available at http://ro.uow.edu.au/cgi/viewcontent.cgi?article=2414\&context=lhapapers (last visited on Oct. 31, 2016). The authors argued that there are 12 maritime features in the Spratly Islands that qualify as 'islands.' They are: (1) Itu Aba occupied by Taiwan; (2) Thitu Island, West York Island, Northeast Cay, Nanshan Island, Loaita Island occupied by the Philippines; and (3) Spratly Island, Southwest Cay, Sin Cowe Island, Sandy Cay, Namyit Island, Amboyna Cay occupied by Vietnam. 
maritime features identified by the Philippine Memorial. The Philippines was invited to provide historical, anthropological, geographic and hydrographic information concerning these twelve features at least. ${ }^{35}$ Philippine legal team then retained one of the scholars (Clive Schofield) advocating "the existence of twelve islands" to help in answering this question, who then denied in the court room what he had written. ${ }^{36}$

'Taiwan factor' became even more salient in the Philippines' Further Written Arguments. Question 15 from the Tribunal directed the Philippines to comment on the relevance to the interpretation of USL of the remarks of the President of Taiwan Authority of China, Dr. Ma Ying-Jeou, dated September 1, 2014 at the opening ceremony of an exhibition of historic archives. ${ }^{37}$ Several points need to be noted. First, the Taiwan government was called by the Tribunal and the Philippines as "Taiwan Authority of China." The legal implications are as follows: (1) Taiwan is considered as part of the State of China as the Respondent in this arbitration; (2) Taiwan Government is not deemed as the representative of China; and (3) People's Republic of China Government ("PRC") acts as China's representative.

Second, not representing China presently, the Republic of China Government ("ROC") in 1947 represented China. This is why in this arbitration Taiwan was considered fit to clarify the meaning of the actions by the then ROC in $1947^{38}$ and $1935 .^{39}$ As the creator and interpreter of USL, Taiwan might substantiate, broaden, or undermine the SCS legal positions of the PRC that has claimed USL since 1949 as the successor of the ROC. Extraordinarily, in this arbitration a government not representing a State is deemed capable of speaking for that State on vital matters of territorial sovereignty and historic maritime claims. Question 15 thus conflicted with itself.

Third, according to the Philippines, the remarks of President Ma on September 1, 2014 clarified that: (1) the 1947 map depicted USL as a claim to the islands, instead of all the waters enclosed; (2) concerning SCS maritime claims "the land dominates the sea" principle was maintained by the then ROC; (3) the spatial extent of its maritime

35 Supplemental Written Submissions of the Philippines [hereinafter SWS] dated on March 16, 2015, at 116-7, available at $\mathrm{http} / /$ www.pcacases.com/pcadocs/Supplemental\%20Written\%20Submission\%20Volume\%20I.pdf (last visited on Oct. 31, 2016).

36 Id. at 118. See also SWS (vol. IX), annex 513, available at http://www.pcacases.com/pcadocs/The $\% 20$ Philippines\%27\%20Supplemental\%20Written\%20Submission\%20-\%20Volume\%20IX\%20\%28Annexes\%20500521\%29.pdf (last visited on Oct. 31, 2016).

37 Supra note 35 , at $83-8$.

$38 I d$. at $85 \& 87$, 9 15.7-15.8 \& 15.12. In 1947, the then ROC Government published a map titled, "Location Map of the SCS Islands 南海諸島位置圖."

39 Id. at 85-6, $\uparrow$ T 15.7 \& 15.9. In 1935, the then ROC Government published a map titled, "Map of Chinese Islands in the SCS 中國南海各島嶼圖.” 
claims was determined by international law at that time; and (4) international law existing in 1947 restricted the then ROC's maritime claims to between 3 and 12 nautical miles out of its claimed insular features. ${ }^{40}$

Fourth, the Philippines concluded that President Ma rejected the 'claim' first asserted by Beijing authorities in 2009 that China is sovereign, or enjoys sovereign rights over, all of the waters within USL. ${ }^{41}$ President Ma's remarks, as interpreted by the Philippines, ${ }^{42}$ made it groundless for China to invoke 'historic right' to justify its maritime claims in the entire waters within USL. It goes without saying that the 1993-2005 SCS Policy Guidelines of Taiwan claiming USL as ‘outer limits' of China's 'historic waters, ${ }^{43}$ would lose historic foundations altogether.

\section{Taiwan's Official Statements on July 7, 2015}

On the first day of the July Hearing, Taiwan's Foreign Ministry released a Statement on the SCS, ${ }^{44}$ with following messages. First, "in December 1947 [the then ROC] issued the revised names of the SCS islands and the Location Map of the SCS Islands, which delineate the scope of [the then] ROC territory and waters in the region." 45 Accordingly, USL also served to delineate the waters in SCS as a maritime boundary. It was obviously a rebuttal to the foregoing Philippine interpretation of President Ma's statement on September 1, 2014.

Second, Taiping Island was described as the largest naturally formed island

$40 I d$. at 83 \& $85-8$, $15.2 \& 15.7-15.13$.

41 Id. at $87-8$, 15.13. The PRC Government actually did not claim all the waters within USL in 2009. See Gau, supra note 13 , at $175-81$.

42 Mr. Chih-Kung Liu, the Representative of Taipei Representative Office in the UK, posted his correction note in The Economist to refute such theory of the Philippines.

SIR - In response to the Banyan column ("Joining the dashes", October 4th), I would like to clarify the position of the Republic of China (Taiwan) on the sovereignty of the islands in the South China Sea. When President Ma Yingjeou spoke last September at the opening ceremony of the Exhibition of Historical Archives on the ROC's Southern Territories, he stated that when the ROC reclaimed and announced its sovereignty over the islands and their surrounding waters in 1947, the law of the sea existing at the time did not provide for maritime regimes other than territorial seas and contiguous zones. President Ma did not say that the ROC's claim was limited to the islands and three to 12 nautical miles of their adjacent waters, since the Location Map of the South China Sea Islands, published by the ROC government in 1947, covers both the islands and their surrounding waters.

See Letters to the Editors, Economist, Nov. 1, 2014, available at http://www.economist.com/news/letters/21629213letters-editor (last visited on Oct. 31, 2016). This clarification was not reported by the Philippines in its answer to Question 15.

43 Michael S.T. Gau, The U-Shaped Line and a Categorization of the Ocean Disputes in the South China Sea, 43 OCEAN DEv. \& INT'L L.58 (2012), available at http://www.tandfonline.com/doi/abs/10.1080/00908320.2012.647499?journalC ode=uodl20 (last visited on Oct. 31, 2016).

44 See ROC's Statement on the SCS, available at http:/www.mofa.gov.tw/en/News_Content.aspx?n=0E7B91A8FBEC4 A94\&sms=220E98D761D34A9A\&s=EDEBCA08C7F51C98 (last visited on Oct. 31, 2016).

$45 \quad I d$ - 2. 
in Nansha (Spratly) Islands, garrisoned by troops from Taiwan since 1956. It has been put under administrative jurisdiction of Kaohsiung City of Taiwan in 1990, with military and civilian personnel dwelling there for past six decades. It has groundwater wells, natural vegetation and fishery resources. Taiping Island should be capable of generating EEZ and continental shelf. ${ }^{46}$ This refuted the Philippine Memorial and Further Written Arguments which denied Itu Aba the status of an island.

Third, "the [then] ROC was a founding member of the UN. Although the ROC lost its representation in 1971, its full name remains in Articles 23 and 110 of UN Charter." "It demonstrated the "One-China Principle," as the UN recognized the PRC as the representative of the State of China, instead of a new UN Member State since 1971. This point could facilitate the PRC in using Taiping Island to claim EEZ and continental shelf against the Philippines.

\section{New Contentions of the Philippines in November Hearings}

Facing factual evidence from Taiwan in asserting Itu Aba as an island, ${ }^{48}$ the Philippines' legal team in November Hearing provided far-reaching contentions. First, the 1896 Qing Empire's Complete Map of All Provinces confirmed what all previous maps of China had shown, i.e., imperial China claimed no territory or waters south of Hainan. ${ }^{49}$ It was not until 1935 that China started to claim SCS territories to the south of the Paracel Islands, as 'testified' by President Ma Ying-Jeou of Taiwan Authority of China. ${ }^{50}$ It implied that China, without 'original title' over the SCS disputed islands (especially the Spratly Islands), should bear the burden to prove that it has successfully acquired territorial sovereignty over certain SCS islands by virtue of particular actions after $1935^{51}$

Second, the 1946 ROC naval recovery of the Spratly and the Paracel Islands failed

$46 \quad I d .93$.

$47 \quad I d .95$.

48 See Our Island: The Atlas of Taiping Island of ROC (Taiwan) (vol. 1), available at http://www.mofa.gov.tw/Upload/ RelFile/1125/150640/848fe97d-1e7c-4ad1-95f4-86b922f9fceb.pdf (last visited on Oct. 31, 2016).

49 Final Transcript Day 1-Merits Hearing (Nov. 24, 2015), at 85-6. See also supra note 4.

50 The Philippines argued on November 24, 2015:

China only claimed islands south of the Paracels for the first time in 1935, when it prepared a map depicting various insular features in the Spratlys. You can see a copy on the screen. President Ma refers to this map as "proclaiming sovereignty" over these features "for the first time".

Id. at 92. See also Merits Award, 9197.

51 Sovereignty over Pedra Branca/Pulau Batu Puteh, Middle Rocks and South Ledge (Malay. v. Sing.), Judgment, 2008 I.C.J., ๆ 42 (May 23), available at http://www.icj-cij.org/docket/files/130/14492.pdf (last visited on Oct. 31, 2016). 
to confer territorial titles over these islands upon China. The 1951 San Francisco Peace Treaty and the 1952 ROC-Japan Peace Treaty did not transfer territorial titles over Spratly and Paracel Islands to China. ${ }^{52}$ Such Philippine arguments implied that, without original titles, China had repeatedly failed to acquire territorial titles over these islands in 1946, 1951, and 1952. Therefore, even if Taiping Island and other maritime features in the Spratly Islands qualify as islands, the EEZ and continental shelf generated thereby cannot accrue to China. ${ }^{53}$

Third, President Ma on September 1, 2014 publicly elaborated the publication of the 1947 map. "... [W]hen [ROC] issued the Location Map of the SCS Islands in 1947, aside from the concept of territorial sea, no other concepts regarding maritime zones existed, nor had any claims been made." ${ }^{54}$ It ruled out the possibility for USL contained in the 1947 map to serve as outer limits of China's maritime claims made through that map.

Fourth, in the decades after 1947, "China made no attempt to claim historic rights in the waters enclosed by that line. ... China adhered to the rules of general international law, which at that time restricted a coastal state's maritime rights to a 3-mile belt of territorial sea. China confirmed that position during the UN Conference on the Law of the Sea ("UNCLOS II") negotiations in 1960."55 Therefore, thanks to the remarks by officials from Taiwan made in 1960 at UNCLOS II, the historic rights later claimed by the PRC from 2009 in the entire area within USL, as seen by the Philippines, were without foundations in history.

Fifth, no feature in the Spratly Islands generated EEZ or continental shelf. No human settlement existed on any feature until mid-20th century, proving their non-habitability. Itu Aba and other features in the Spratly Islands were always militarily occupied to establish and reinforce sovereignty claims. Military bases were insufficient to prove an insular feature to be capable of sustaining human habitation or economic life of its own. ${ }^{56}$ Taiwan's Statement on the SCS on July 7, 2015 and subsequent Statement on October 31, 2015 lacked evidence to prove that Itu Aba could sustain human habitation, ${ }^{57}$ as no fresh water, no natural nourishment, and no soil existed there. ${ }^{58}$ The report prepared by Prescott and Schofield for the Philippines

52 Final Transcript Day 2-Merits Hearing (Nov. 25, 2015), at 1-2.

53 Such line of arguments should have been banned by the Tribunal, as they aimed at resolving territorial disputes by denying China's titles over certain territories.

54 Final Transcript Day 2-Merits Hearing (Nov. 25, 2015), at 3-4.

55 Id. at 5 .

56 Id. at 96-102.

57 Id. at $108-18$.

58 Final Transcript Day 4-Merits Hearing (Nov. 30, 2015), at 41. 
assessed Itu Aba as having "no permanent indigenous population, the personnel stationed there are reliant on supplies provided from outside and there is no evidence of meaningful economic activity ongoing or in the past."

Sixth, it was not until July 7, 2015 that Taiwan started to claim EEZ and continental shelf out of Itu Aba. The timing was after the critical date of this arbitration. ${ }^{60}$ Moreover, this claim violated Taiwan's 1998 Law on the Territorial Sea and the Contiguous Zone, as no baseline had been decided yet for Itu Aba. ${ }^{61}$ Therefore, Taiwan's SCS Statement on July 7, 2015 declaring EEZ and continental shelf surrounding Itu Aba was illegitimate under its own law. Assuming Taiwan allows the PRC to use EEZ and continental shelf generated by Itu Aba to fight against Philippine arguments, the PRC would receive nothing usable.

Seventh, the Philippines considered that there was only one China. Since 1949, only the PRC spoke for China. The actions of predecessor governments prior to 1949, including the then ROC were attributable to China. The actions of Taiwanese authorities since 1949 were not per se attributable to the PRC. ${ }^{62}$ This clever contention meant that the Philippines and the Tribunal may still find a way to consider certain post-1949 official acts of Taiwan attributable to China, as indicated above.

\section{E. Taiwan's Further Statements and Amicus Curiae Brief}

As the Philippines heavily criticized the evidence of Taiwan's statements on SCS issues in November Hearing, Taiwan fought back. On January 23, 2016, Taiwan's Foreign Ministry produced a Press Release to provide more factual information about Taiping Island. ${ }^{63}$ On January 28, 2016, President Ma visited Taiping Island, speaking there about ancient China's territorial sovereignty over SCS islands and presented the facts about Taiping Island, as follows.

First, "[in] response to the ... dispute regarding sovereignty over SCS Islands and maritime rights, ... these islands were first discovered, named, and used by the Chinese in the Western Han dynasty (in the first century BCE). They were incorporated into the maritime defense system no later than 1721, in the Kangxi

59 Final Transcript Day 2-Merits Hearing (Nov. 25, 2016), at 117. See also C. Schofield, et al., An Appraisal of the Geographical Characteristics and Status of Certain Insular Features in the South China Sea (Mar. 2015), SWS (vol. IX), annex 513, at 24.

60 Final Transcript Day 4-Merits Hearing (Nov. 30, 2015), at 38.

61 Id. at 39-40.

62 Final Transcript Day 2-Merits Hearing (Nov. 25, 2016), at 6.

63 See Taiping Island is an island, not a rock, and the ROC possesses full rights associated with an EEZ and continental shelf in accordance with UNCLOS, The Press Release (No. 023), available at http://eng.coa.gov.tw/content_view. php?catid $=2504180 \&$ hot_new $=8790$ (last visited on Oct. 31, 2016). 
period of the Qing dynasty, with patrols and other management measures." was to refute the Philippines' argument that before 1896 China had claimed no territories south of Hainan Island.

Second, "the Philippines ... holds that Taiping Island has no freshwater, and no arable soil, claiming that food and water must all be imported and human habitation is impossible. This ... means that it is not an island, but a rock ... [Such] statements ... are totally wrong." ${ }^{65}$ President Ma then walked around Taiping Island to show whereabouts of fresh water, soil, natural vegetation, 106 land-based indigenous plant species, and lots of fruits and livestock there. ${ }^{66}$ The video provided vivid illustration of this tour. ${ }^{67}$

On March 21, 2016, the Ministry of Foreign Affairs in Taiwan issued the Position Paper on its SCS policy, as a comprehensive legal and policy statement of Taiwan's position for this Arbitration. ${ }^{68}$ On March 23, 2016, an amicus curiae brief prepared by Chinese (Taiwan) Society of International Law ("CSIL") ${ }^{69}$ was open to many foreign journalists, after Professor Chun-I Chen visited Taiping Island. Professor Chen was introduced by President Ma who hosted the evening press conference. ${ }^{70}$ CSIL, a private institution, does not speak for any government. Introduced at President Ma's press conference, the Amicus Curiae brief seemed to have official endorsement. This document focused on the factual situations of Itu Aba with plenty of scientific evidence provided by experts. ${ }^{71}$ It testified that this feature qualified as an island under Article 121(1), instead of a rock under Article 121(3). At this press conference, President Ma formally invited the Philippines to send representatives to visit Itu Aba. $^{72}$

Remarks by President Ma on Taiping Island dated on January 28, 2016, available at http://english.president.gov.tw/ Default.aspx?tabid=491\&itemid=36616\&rmid=2355 (last visited on Oct. 31, 2016).

65 Id.

66 Id.

67 See Office of the President video, available at http://www.president.gov.tw/Default.aspx?tabid=131\&rmid=514\&item $\mathrm{id}=36615$ (last visited on Oct. 31, 2016).

68 Position Paper of ROC on the South China Sea, available at http://multilingual.mofa.gov.tw/web/web_UTF-8/South/ Position\%20Paper\%20on\%20ROC\%20South\%20China\%20Sea\%20Policy.pdf (last visited on Oct. 31, 2016).

69 See the amicus curiae brief, Mar. 23, 2016, available at http://csil.org.tw/home/wp-content/uploads/2016/03/SCSTFAmicus-Curiae-Brief-final.pdf. For the audio conversation see AMTI Podcase: Itu Aba \& Taiwan's Amicus Brief, available at $\mathrm{https}: / /$ amti.csis.org/podcast (all last visited on Oct. 31, 2016).

70 See The video of President Ma's Press Conference, including Professor Chen's briefing on amicus curiae, available at http://www.president.gov.tw/Default.aspx?tabid=131\&itemid=36979\&rmid=514; The text of President Ma's statement in English at this press conference, available at $\mathrm{http} / /$ english.president.gov.tw/Default.aspx?tabid=491\&itemid=36980 \&rmid=2355 (all last visited on Oct. 31, 2016).

71 All the appendices of amicus curiae brief, available at https://www.dropbox.com/sh/00hisxaaksj06la/ AABz2YgCiPZKY7GwUc5nik64a?dl=0 (last visited on Oct. 31, 2016).

72 Supra note 70. 


\section{F. The Philippines' Responses to Taiwan's Further Arguments}

Noticing the above Statements from Taiwan, the Tribunal asked the Philippines and China for comments. On March 11, 2016, the Philippines provided its Responses to the Tribunal's Request for Comment of February 5, 2016, refuting Taiwan's Statements dated on January 23-28, 2016. ${ }^{73}$ Later on April 25, 2016, the Philippines offered its Responses to the Tribunal's Request for Comments of April 1, 2016 on Additional Materials regarding the Status of Itu Aba, denying Taiwan's Statements dated on March 21-23, 2016. ${ }^{74}$

On June 3, 2016, the Philippines submitted its Responses to the Tribunal's Request for Comments of May 25, 2016 on Materials from the French Archives. They were not responding to Taiwan's Statements but still touching upon Itu Aba. ${ }^{75}$ According to the Philippines, the French Archives "confirmed that prior to the Second World War France did not consider China to have made a claim in regard to any of the Spratlys." Additionally, "France retained its claim to those features."

\section{G. The Merits Award and Taiwan}

Though knowing the relevant statements and evidence from Taiwan, "t7 "the Tribunal considered historic records concerning the conditions on features in the Spratly Islands, including Itu Aba, prior to them having been subjected to significant human modification, to be more relevant than evidence of the situation currently prevailing." ${ }^{78}$ Hence, the Tribunal declined the formal invitation to visit Itu Aba offered by President Ma from the Taiwan Authority of China. ${ }^{79}$ Based on the record, the Tribunal considered:

[t] he best sources of water in the Spratly Islands appear to have been on Itu Aba and South-West Cay. ... The freshwater resources of these features, combined presumably with rainwater collection, evidently have supported small number of people in the past... they are therefore able to do so in their natural condition. ${ }^{80}$... Itu Aba and Thitu ... have been the most heavily forested features in their natural condition ... at least

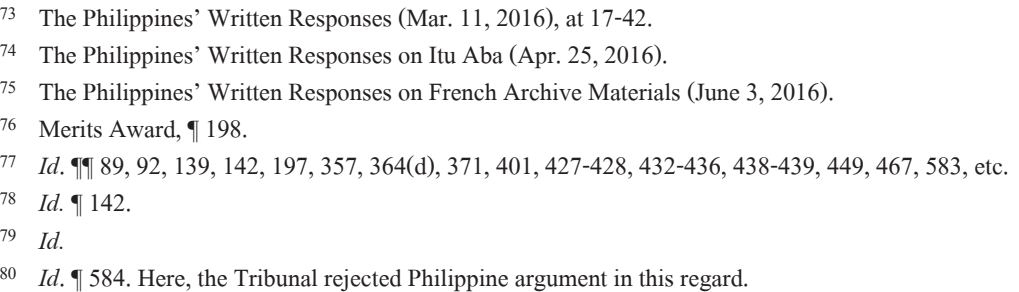


Itu Aba appears to have been amenable to the introduction and cultivation of papaya and banana trees, even if such species do not necessarily appear to have been naturally occurring. ${ }^{81}$

The Tribunal considered: “...fruit and vegetables were being grown on Itu Aba during the period of Japanese commercial activity. ... [N]o evidence [proved] that this would have involved the importation of soil." ${ }^{, 82}$ The Tribunal concluded:

[i]t most likely reflects the capacity of the feature in its natural condition. ... the capacity for such cultivation would be limited and that agriculture on Itu Aba would not suffice, on its own, to support a sizable population. ${ }^{83}$... No evidence of any commercial fishing operation having been established in the Spratly Islands since 1945. Nor, in light of the advances in shipbuilding and fishing technology since that date, does the Tribunal see that a base of operations on a small, isolated feature such as Itu Aba would be economically necessary, or even beneficial. ${ }^{84}$

Finally, when viewing "historical human habitation of the features of the Spratly Islands," the Tribunal considered:

Human habitation to entail the non-transient inhabitation of a feature by a stable community of people for whom the feature constitutes a home and on which they can remain. This standard is not met by the historical presence of fishermen that appears in the record before the Tribunal. ${ }^{85}$ The same conclusion holds true with respect to Japanese commercial activities on Itu Aba and South-West Cay. A crew of Formosan laborers, brought to the Spratlys to mine guano or capture sea turtles, is inherently transient in nature... ${ }^{86}$

The military or other governmental personnel presently stationed on the features in the Spratly Islands by one or another of the littoral States [do not] suffice to constitute 'human habitation' for the purposes of Article 121(3). These groups are heavily dependent on outside supply, and it is difficult to see how their presence on any of the SCS features can fairly be said to be sustained by the feature itself, rather

Id. $₫ 593$

2 Id. 9 596. The Tribunal rejected the Philippine position on this issue.

83 Id. 614.

84 Id. 1614.

85 Id. 1618.

$86 \quad I d . \rrbracket 619$. 
than by a continuous lifeline of supply and communication from the mainland. ${ }^{87}$

The introduction of EEZ was not intended to grant extensive maritime entitlements to small features whose historical contribution to human settlement is as slight as that. Nor was EEZ intended to encourage States to establish artificial populations in the hope of making expansive claims, precisely what has now occurred in SCS. On the contrary, Article 121(3) tries to prevent such developments and to forestall a provocative and counterproductive effort to manufacture entitlements. ${ }^{88}$

Concerning "historical economic life of their own of the features of the Spratly Islands," the Tribunal concluded:

all of the economic activity in the Spratly Islands that appears in the historical record has been essentially extractive in nature (i.e., mining for guano, collecting shells, and fishing), aimed to a greater or lesser degree at utilising the resources of the Spratlys for the benefit of the populations of Hainan, Formosa, Japan, the Philippines, Viet Nam, or elsewhere. ..., To constitute the economic life of the feature, economic activity must be oriented around the feature itself and not be focused solely on the surrounding territorial sea or entirely dependent on external resources. ... Extractive economic activity, without the presence of a stable local community, necessarily falls short of constituting the economic life of the feature. ${ }^{89}$

Applying this standard, the history of extractive economic activity does not constitute, for the features of the Spratly Islands, evidence of an economic life of their own. ... The effect of Article 121(3) is to prevent such features - whose economic benefit, if any, to the State which controls them is for resources alone -from generating a further entitlement to a 200-M EEZ and continental shelf that would infringe on the entitlements generated by inhabited territory or on the area reserved for the common heritage of mankind. ${ }^{90}$

Therefore, "none of the high-tide features in the Spratly Islands is capable of sustaining human habitation or an economic life of their own, the effect of Article 121(3) is that such features shall have no exclusive economic zone or continental shelf." ${ }^{11}$ 


\section{Conclusion}

Finally, Taiping Island occupied by Taiwan was held by the Tribunal to be incapable of generating EEZ and continental shelf, as such other smaller features in the Spratly Islands. Therefore, China was held without EEZ and continental shelf entitlements in WPS. Those LTEs occupied by the PRC were held to be located outside China's EEZ and continental shelf. China's trespass into the Philippine EEZ and continental shelf was held to be true.

Since July Hearing in 2015, Taiwan Government has actively engaged in the legal and factual debates with the Philippines, as if it were the Respondent of this case for certain matters. Critically, the Tribunal declined the invitation offered by President Ma to visit Taiping Island. Had the Arbitrators visited Taiping Island and stayed there for a while, would this Tribunal have decided differently? A doubt lingers.

Another important question arises. Why did President Ma and CSIL's amicus curiae not touch upon legal issues of interpretation of Article 121? With the Tribunal's attention paid to Taiwan's statements prepared by heavyweight experts of international law, a huge difference could have been made had they challenged Philippine position on this fundamental issue of treaty interpretation. After all, the Merits Award did reject certain Philippine arguments regarding factual situations of Taiping Island! 